\title{
THE RELATIONSHIP BETWEEN VERBAL ABILITY AND CRITICAL THINKING SKILL: THE IMPLEMENTATION OF SUSAN LOUCKS HORSLEY MODEL
}

\author{
Ana Yuniasti Retno Wulandari*1, Nurhayati ${ }^{2}$ \\ ${ }^{1,2}$ University of Trunojoyo Madura \\ *Correspondence address: ana.wulandari@trunojoyo.ac.id
}

Accepted: January $25^{\text {th }}, 2018$. Approved: April 12 ${ }^{\text {nd }}, 2018$. Published: April $28^{\text {th }}, 2018$

\begin{abstract}
Susan Loucks Horsley is a learning model that can connect science and technology. This model can help students adapt to the increasingly changing scientific and technology of the $21^{\text {st }}$ century. Students are challenged with issues that require the use of scientific information, technology, verbal ability, critical thinking, and conceptual understanding in making decisions. It is because verbal ability and critical thinking are needed in solving problems hence this research aims to know the correlation of verbal ability with students' critical thinking skill in science learning of vibration, wave and sound material using Susan Loucks Horsley model. The sample of this research is the students of VIII A SMP N 1 Pamekasan. The collecting data technique use tests to measure the students' verbal ability and critical thinking skills. The data analysis uses Pearson correlation. The result of this research shows there is a correlation between verbal ability with students' critical thinking skill in science learning of vibration, wave and sound material using Susan Loucks Horsley model with the value of Pearson correlation coefficient 0,656 and significance 0.000. This research has an implication that the teachers should be appropriate in applying the learning model that can grow the students' verbal ability and critical thinking skill.
\end{abstract}

C 2018 Physics Education, UIN Raden Intan, Lampung, Indonesia

Keywords: conceptual understanding, critical thinking, susan loucks horsley, verbal ability

\section{INTRODUCTION}

Conceptual understanding is necessary for the study of physical science. This is because conceptual understanding becomes the basis for thinking in solving various problems (Irwandani \& Rofiah, 2015). Students can transfer an explanation of a phenomenon to different situations (Kola, 2017).

However, students' conceptual understanding of physical science in Indonesia is still categorized as low (Adilah \& Pujayanto, 2015). Students still have problems to understand the concepts of physics that have been studied (Saleh, 2011). Lack of students conceptual understanding leads to difficulty in solving problems (Holme, Luxford, \& Brandriet, 2015). Students difficulties mostly arise from the problem of understanding the word, the difficulty of making plans and defining related vocabulary (Seifi, Haghverdi, \& Azizmohamadi, 2012).

Vibration, wave, and sound are one of the eighth-grade science materials in junior high school. To learn about the concept of vibrational, waves and sounds material requires the understanding of some terms, symbols, formulas, and images. Therefore, good verbal ability needs to be owned by students (Vukovic \& Lesaux, 2013).

Verbal ability is the ability that includes understanding vocabulary, verbal analogy, and others (Vukovic \& Lesaux, 2013; Walgito, 2010). Verbal ability is usually demonstrated as the ability to write and speak well (Andrew, Cobb, \& Giampietro, 2005). A good verbal ability can help the student in understanding the material, interpreting the questions quite complex and drawing conclusions (Daniyati \& Sugiman, 2015). 
Therefore, required a learning model that can facilitate students in understanding the concept and train students' verbal ability. Susan Loucks Horsley is a learning model that can connect between science and technology, involves the process of analysis, and train students to compile answers from various sources of information that will be delivered based on related questions (Liliawati, Utama, \& Fauziah, 2016). Susan Loucks Horsley's model consists of four learning stages: invited, explore and discover, purpose explanation, taking action (Loucks-Horsley, Stiles, Mundry, Love, \& Hewson, 2010; Muiz, Wilujeng, Jumadi, \& Senam, 2016; Nurhayati, Jumadi, Wilujeng, \& Senam, 2017).

Susan Loucks Horsley's model is also expected to grow students' critical thinking skills (Jumadi, Paidi, Atiarani, \& Siwi, 2014). Critical thinking skills are needed to analyze and solve a problem in everyday life (Wulandari, 2017). Critical thinking is thinking that makes sense and focused reflection to decide what should be believed or done (Fisher, 2014).

When doing critical thinking tests, students must be able to understand the meaning of the test question. To understand the meaning of the problem required students' verbal skills. Therefore, students' verbal ability related to students' critical thinking skills in solving problems. James \& Adewale suggests that there is a relationship between verbal ability with problem-solving abilities (James \& Adewale, 2012). If students misunderstand the meaning of the question will make the students wrong in determining the problem-solving strategy so that the results obtained are also wrong (Daniyati \& Sugiman, 2015).

To achieve a good learning outcome, students must have a good verbal ability (Olatoye \& Aderogba, 2011). The research result of Nurbaeti, et.al shows that there is a relationship between critical thinking skills positively with students' cognitive abilities on the subjects of Chemistry class $\mathrm{X}$ SMKN 1 Bungku Tengah (Nurbaeti, Nuryanti \& Puspitasari, 2015). It is similar to the Adeyemi's research that in Nigeria, student learning outcomes increase significantly when teachers use learning that trains students' critical thinking skills (Adeyemi, 2012).

Based on the results of relevant research above is known that the verbal ability and critical thinking skills are closely related to learning outcomes. Therefore, this research aims to know the relationship between students' verbal ability and critical thinking skills in vibration, wave, and sound concepts.

\section{METHOD}

This research uses pre-experimental design type one-shot case study. The sample of this research is thirty students of VIII A SMP N 1 Pamekasan. The sampling technique uses purposive sampling. Purposive sampling is a technique to choose the sample with a specific purpose (Creswell, 2014).

The collecting data technique use test to measure the students' verbal ability and critical thinking skill. The verbal ability test instrument consists of 20 questions adapted from Raven and includes vocabulary tests, synonym tests, opponent tests, and verbal analogy tests (Raven, Court, \& Raven, 1977; Widhiarso \& Haryanto, 2015; Yazdi, 2017). The critical thinking skills test instrument consists of 10 essay questions compiled using Ennis's critical thinking indicator: simple explanation, further explanation, inference and set the strategy and tactics (Ennis, 1996; Mabruroh \& Suhandi, 2017).

Before the instrument is used, it is validated to 3 experts i.e 2 lecturers and 1 science teacher. Instrument validity is calculated using the Aiken V formula as in Equation 1 (Aiken, 1985; Azwar, 2015). 
Notes:

$$
V=\frac{\sum \mathrm{S}}{[\mathrm{n}(\mathrm{c}-1)]}
$$

$\mathrm{V}=$ Validity of Aiken's V content

$\mathrm{S}=\mathrm{r}-\mathrm{lo}$

$\mathrm{r}=$ The number given by validators

lo $=$ The lowest validity score

$\mathrm{c}=$ Highest validity score

$\mathrm{n}=$ Number of validators

While the reliability of the instrument is calculated using the Borich formula as in Equation 2 (Borich, 1994).

$R=\left[1-\frac{A-B}{A+B}\right] \times 100 \%$

Notes:

$\mathrm{R}=$ Borich's Reliability

$\mathrm{A}=$ The highest frequency provided by the validator

$\mathrm{B}=$ The lowest frequency provided by the validator

The result of validity calculation is 1.21 and valid to use (Azwar, 2015). While the reliability results obtained value $88,5 \%$ and very reliable (Borich, 1994).

Normality and homogeneity tests are performed before hypothesis testing. Normality test using KolmogorovSmirnov and homogeneity test using Levene test in SPSS 20 application. The hypothesis test uses Pearson correlation in SPSS 20 application to analyze the relationship between students' verbal ability and critical thinking skill in vibration, wave, and sound material.

The data of students' verbal ability and critical thinking skill that have been collected are then categorized using criteria in Table 1 (Firdaus, Kailani, Bakar, \& Bakry, 2015).

Table 1. The range of score in verbal ability and critical thinking

\begin{tabular}{ll}
\hline $\begin{array}{l}\text { The range of } \\
\text { Score \% }\end{array}$ & $\begin{array}{l}\text { Levels of students' verbal } \\
\text { ability and critical thinking }\end{array}$ \\
\hline$X \geq 80$ & Excellent \\
$60 \leq X<80$ & Good \\
$40 \leq X<60$ & Fair \\
$20 \leq X<40$ & Poor \\
$X<20$ & Very Poor \\
\hline
\end{tabular}

\section{RESULT AND DISCUSSION}

Implementation of the learning model of Susan Loucks Horsley conducted for 3 meetings. The first meeting to learn the concept of vibration, the second meeting to learn the concept of the wave, and the third meeting to learn the concept of sound. After that, a test is done to measure the students' verbal ability and critical thinking skills.

Some examples of students' answers to the verbal ability test can be seen in Figures 1 and 2. While the sample of students' answers to critical thinking test can be seen in Figures 3 and 4.

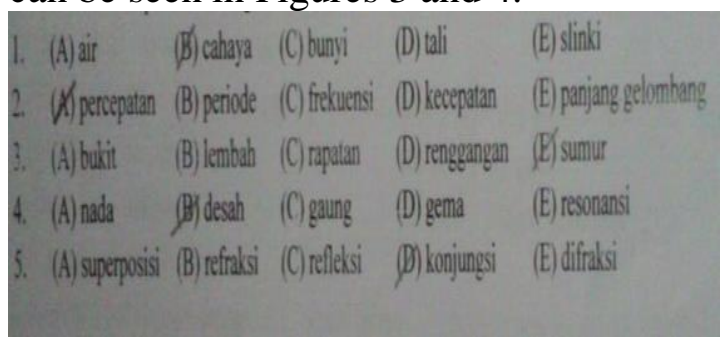

Figure 1. The students' answers to the vocabulary test

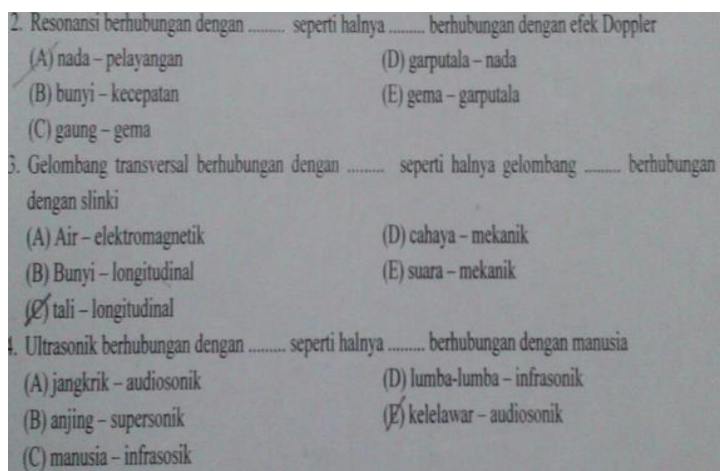

Figure 2. The students' answers to the verbal analogy test

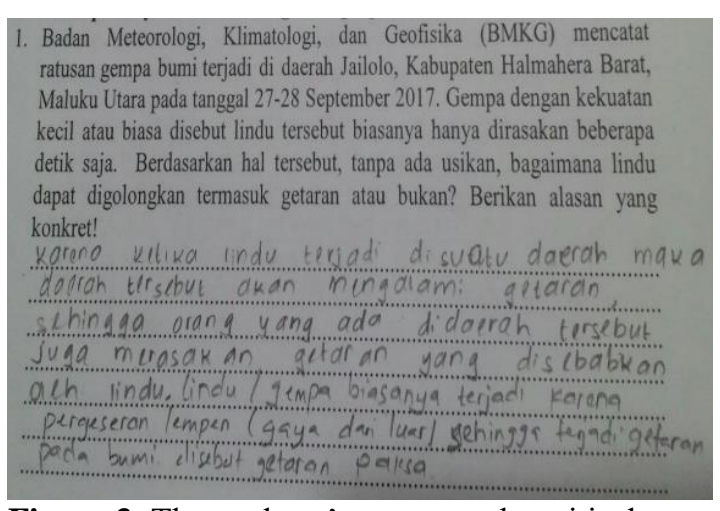

Figure 3. The students' answer to the critical thinking test in simple explanation indicator 


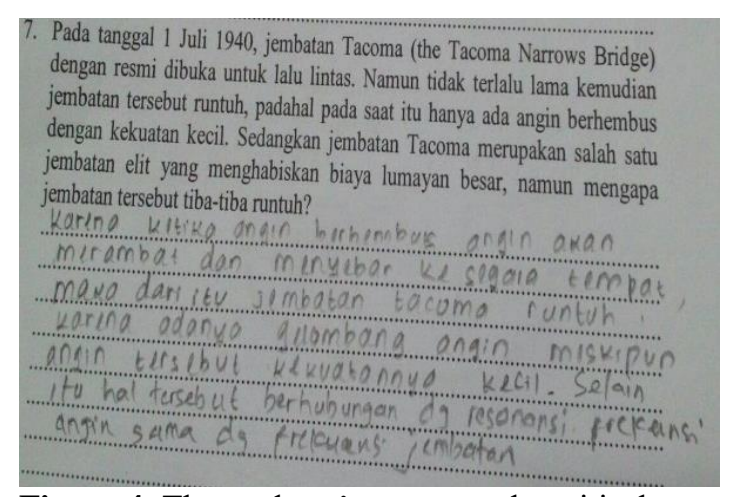

Figure 4. The students' answer to the critical thinking test in inference indicator

Figure 1 shows the students' work on vocabulary tests of verbal skills. In this vocabulary test, there are still some students who are wrong in answering questions 4. Figure 2 shows students' work results on a verbal analogy test. In this verbal analogy test, almost all students are correct in answering. Figure 3 is an example of the student's work on a critical thinking test with an indicator of simple explanation. On this question, most students answer the question correctly to explain small earthquake events. Figure 4 shows the result of the student's critical thinking test on the inference indicator. On the question, there are still some students who have difficulty inferring the cause of the collapse of the Tacoma bridge.

The data of students' verbal ability and critical thinking skill that have been collected are then categorized. The results categorization of students' verbal ability and critical thinking skill can be seen in Table 2.

Table 2. Level of students' verbal ability and critical thinking

\begin{tabular}{lllll}
\hline & \multicolumn{2}{l}{$\begin{array}{l}\text { Verbal } \\
\text { Ability }\end{array}$} & \multicolumn{2}{l}{$\begin{array}{l}\text { Critical } \\
\text { thinking }\end{array}$} \\
\cline { 2 - 5 } Category & F & $\mathbf{( \% )}$ & F & $\mathbf{( \% )}$ \\
\hline Excellent & 19 & 63,3 & 23 & 76,7 \\
Good & 11 & 36,7 & 7 & 23,3 \\
Fair & 0 & 0 & 0 & 0 \\
Poor & 0 & 0 & 0 & 0 \\
very poor & 0 & 0 & 0 & 0 \\
\hline
\end{tabular}

Based on Table 2 it can be seen that 19 students have excellent category in verbal ability $(63,3 \%)$ and 11 students have good category in verbal ability $(36,7 \%)$. For the results of critical thinking skills, it is known that 23 students have critical thinking skills of the excellent category $(76,7 \%)$ and 7 students have critical thinking skills of the good category $(23,3 \%)$. None of the students are in the fair, poor, and very poor category of critical thinking skill and verbal ability. It is because in the second and third stages of Susan Loucks Horsley's model allows activities that can train students' critical thinking skills. While in the fourth stage can stimulate students' verbal ability through communication activities (Muiz et al., 2016).

In the first stage of Susan Loucks Horsley model (Invited stage), teachers provide motivation and ask questions related to the material to be studied. In the second stage of Susan Loucks Horsley model (Explore and discover stage), students are given the opportunity to gather information and even analyze the phenomenon of the problem being faced. It is related to students' critical thinking skills. Students can develop students' critical thinking in the second stage of Susan Loucks Horsley model. Students can practice critical thinking skills through scientific activities that must be done. In the third stage of Susan Loucks Horsley model (Purpose explanation stage), students are given the opportunity to present the findings using their own language. This is related to students' verbal ability. Students can practice verbal ability by communicating the findings and providing the further explanation by linking the previously learned concepts. The vibration, waves, and sound material are a matter related to everyday life. This is related to the last stage of Susan Loucks Horsley model (Taking action stage). At the last stage, 
students can look for examples of the application of the concept of vibration, wave, and sound in everyday life (Loucks-Horsley et al., 2010; Muiz et al., 2016; Nurhayati et al., 2017).

To see clearly the categorization results of students' verbal ability and critical thinking skill, presented in the histogram in Figure 5.

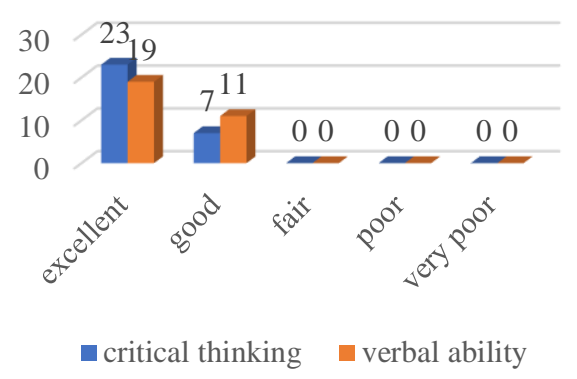

Figure 5. Students' verbal ability and critical thinking skill in learning physics

According to McCormack\& Yager, Susan Loucks-Horsley model is an extension of five domains (knowledge, science process skills, creativity, attitudinal, as well as the application and connection) in science education that does not just develop content and process (McCormack, 1992). The research result of Liliawati, et.al shows that integrated learning with model Susan LoucksHorsley is able to increase students' achievement (Liliawati et al., 2016).

The statistical descriptive results of verbal ability and critical thinking on vibration, wave, and sound material are presented in Table 3.

Table 3. Level of students' verbal ability and critical thinking

\begin{tabular}{lll}
\hline & $\begin{array}{l}\text { Verbal } \\
\text { Ability }\end{array}$ & $\begin{array}{l}\text { Critical } \\
\text { Thinking }\end{array}$ \\
\cline { 2 - 3 } Mean & 80,17 & 83,25 \\
Median & 80,00 & 83,75 \\
Mode & 80,00 & 80,00 \\
Std. Deviation & 8,85 & 7,11 \\
Variance & 78,42 & 50,49 \\
Minimum & 65,00 & 67,50 \\
Maximum & 95,00 & 95,00 \\
Sum & 2405,00 & 2497,50 \\
\hline
\end{tabular}

Based on Table 3 it is known that the average of verbal ability is 80,17 with the standard deviation of 8,85 and the minimum value is 65,00 and the maximum value is 95,00 . The average of critical thinking is 83,25 with the standard deviation of 7,11 and the minimum value 67,50 and the maximum value 95,00 . So, it can conclude that the average of verbal ability and critical thinking are an excellent level. This means that learning with the Susan Loucks Horsley model can train students' verbal ability and critical thinking skills.

This result is similar to some previous research. Based on Muiz's Research is known that the implementation of science learning through the application of Susan LoucksHorsley model can improve communication and collaboration of learners (Muiz et al., 2016). Likewise, the application of Susan Loucks Horsley learning model can improve students learning outcomes (Anjani \& Suyatno, 2015).

Before hypothesis testing, normality and homogeneity tests were performed. The normality test uses KolmogorovSmirnov test in SPSS 20 application. The result of the normality test is presented in Table 4.

Table 4. Test of normality

\begin{tabular}{|c|c|c|c|}
\hline & \multicolumn{3}{|c|}{ Kolmogorov-Smirnov } \\
\hline & Statistic & $\mathrm{df}$ & Sig. \\
\hline $\begin{array}{l}\text { Verbal } \\
\text { ability }\end{array}$ & 0,126 & 30 & 0,200 \\
\hline $\begin{array}{l}\text { Critical } \\
\text { thinking }\end{array}$ & 0,125 & 30 & 0,200 \\
\hline
\end{tabular}

Based on Table 4 it can be seen that the data of verbal ability and critical thinking are normally distributed. This is indicated because the significance of normality test is greater than 0.05 , i.e the significance of verbal ability is 0.200 and the significance of critical thinking is 0.200 . 
The homogeneity test uses Levene test in SPSS 20 application. The result of the homogeneity test is presented in Table 5.

Table 5. Test of homogeneity

\begin{tabular}{lll}
\hline & $\begin{array}{l}\text { Levene } \\
\text { Statistic }\end{array}$ & Sig. \\
\hline Based on Mean & 0.814 & 0.371 \\
$\begin{array}{l}\text { Based on Median } \\
\text { Based on Median }\end{array}$ & 0.754 & 0.389 \\
$\begin{array}{l}\text { and with adjusted df } \\
\text { Based on trimmed } \\
\text { mean }\end{array}$ & 0.754 & 0.389 \\
\hline
\end{tabular}

Based on table 5 it is known that the data is homogeneous. This can be seen from the significance of homogeneity test is greater than 0.05 , which is 0.371 .

The statistic used to test the research hypothesis is Pearson correlation because the data of verbal ability and critical thinking are normally distributed and homogenous. The hypothesis in this research is $\mathrm{H}_{0}$ (there is no correlation between students' verbal ability and critical thinking skill on Susan Loucks Horsley learning model of vibration, waves, and sound material) and $\mathrm{H}_{1}$ (there is a correlation between students' verbal ability and critical thinking skill on Susan Loucks Horsley learning model of vibration, waves, and sound material). The result of Pearson correlation SPSS 20 application is presented in Table 6 .

Table 6. Pearson Correlation

\begin{tabular}{llll}
\hline \multirow{2}{*}{$\begin{array}{l}\text { critical } \\
\text { thinking }\end{array}$} & $\begin{array}{l}\text { Pearson } \\
\text { critical } \\
\text { thinking }\end{array}$ & $\begin{array}{l}\text { verbal } \\
\text { ability }\end{array}$ \\
\cline { 3 - 4 } & $\begin{array}{l}\text { Correlation } \\
\text { Sig. (2-tailed) }\end{array}$ & - & $0,656^{* *}$ \\
& $\mathrm{~N}$ & 30 & 0,000 \\
\hline verbal & Pearson & $0,656^{* *}$ & 1 \\
ability & Correlation & & \\
& Sig. (2-tailed) & 0,000 & - \\
& $\mathrm{N}$ & 30 & 30 \\
\hline
\end{tabular}

Based on Table 6 it is known that the significance of Pearson correlation between students' verbal ability and critical thinking is 0,000 with correlation coefficient 0,656 . Due to the significance of $0.000<0.05$ then $\mathrm{H}_{0}$ is rejected. So, it can be concluded there is a correlation between students' verbal ability and critical thinking skill on Susan Loucks Horsley learning model of vibration, waves, and sound material. The correlation can be seen that the higher result of students' verbal ability then the students' critical thinking is also getting better. It is similar to the Irawan's research that there is an influence of verbal ability on students' critical thinking (Irawan, 2016). Students need critical thinking skills to translate the verbal statement of the problems encountered so as to solve the problem well (Awofala, 2014).

In solving the problem of critical thinking is also influenced by the students' verbal ability. Students who have high verbal ability can easily understand the intent of the problem, analyze and communicate the answers in written form (James \& Adewale, 2012). Verbal ability is the ability of students in pouring knowledge and experience possessed in the form of adequate language, so that can be communicated to others (Vukovic \& Lesaux, 2013). While, critical thinking is defined as a high level of ability that drives or regulates an individual to be able to think using logic, to prove an argument by way of thinking, and to evaluate opinions rationally (Nasrun, 2014). Critical thinking can be used in the formation of student conceptual systems (Purnamawati, Ertikanto, \& Suyatna, 2017).

The result of this research is similar to the research of James \& Adewale by concluding that there is a relationship of verbal ability with problem-solving abilities (James \& Adewale, 2012). It is according to Elliott because the first and most basic step in problem-solving is to represent the information in either 
symbolic or diagrammatic form. While (Elliott, Kratochwill, Cook, \& Travers, 1996), critical thinking involves the ability to evaluate problems so that good conclusion can be drawn (Burke, Sears, Kraus, \& Cady, 2014). Therefore, verbal ability and critical thinking skills need to be owned by students.

\section{CONCLUSION}

The result of this research shows there is a correlation between students' verbal ability toward critical thinking skill with Pearson correlation coefficient 0,656 and significance 0,000 . The correlation can be seen that the higher result of students' verbal ability then the students' critical thinking skill is also getting better.

This research has an implication that the teachers should be appropriate in applying the learning model that can grow the students' verbal ability and critical thinking skill. The limitation of this research is to use only one class of experiments and the measurement of verbal and critical thinking tests is only done at the end of the lesson. Future researchers are needed to explore the contribution of Susan Loucks Horsley model on students' critical thinking skills and verbal ability using experiment and control class.

\section{REFERENCES}

Adeyemi, S. B. (2012). Developing Critical Thinking Skills in Students: A Mandate for Higher Education in Nigeria. European Journal of Educational Research, 1(2), 155161.

Adilah, D. ., \& Pujayanto. (2015). Eksperimen Blended Learning dan Learning Cycle 7E Pada Sub Tema Pengelolaan Sampah Ditinjau Dari Motivasi Belajar Siswa Kelas VII SMPN 6 Surakarta. Jurnal Materi Dan Pembelajaran Fisika, 5(1), 4249.

Aiken, L. R. (1985). Three Coefficients for Analyzing The Reliability, and Validity of Ratings. Educational and Psychological Measurement, 45, 131-142.

Andrew, M. ., Cobb, C. ., \& Giampietro, P. . (2005). Verbal Ability and Teacher Effectiveness. Journal of Teacher Education, 56(4), 343-354.

Anjani, D., \& Suyatno, W. (2015). Implementasi Model Pembelajaran Susan Loucks-Horsley untuk Meningkatkan Hasil Belajar pada Pelajaran Kimia. In Prosiding Seminar Nasional Kimia (pp. 115119). Surabaya: FMIPA UNESA.

Awofala, A. O. . (2014). Examining Personalisation of Instruction, Attitudes toward and Achievement in Mathematics Word Problems among Nigerian Senior Secondary School Students. International Journal of Education in Mathematics, Science, and Technology, 2(4), 273-288.

Azwar, S. (2015). Reliabilitas dan Validitas. Yogyakarta: Pustaka Pelajar.

Borich, G. . (1994). Skills Observation for Effective Teaching (2nd ed.). New York: Macmillan Publishing Company.

Burke, B. ., Sears, S. ., Kraus, S., \& Cady, S. . (2014). Critical Analysis: A Comparison of Critical Thinking Changes in Psychology and Philosophy Classes. Teaching of Psychology, 41(1), 28-36. https://doi.org/10.1177/00986283135 14175

Creswell, J. W. (2014). Research Design: Pendekatan Kualitatif, Kuantitatif, dan Mixed. Yogyakarta: Pustaka Pelajar.

Daniyati, N. ., \& Sugiman. (2015). Hubungan Antara Kemampuan Verbal, Kemampuan Interpersonal, dan Minat Belajar Dengan Prestasi Belajar Matematika. PYTHAGORAS: Jurnal Pendidikan Matematika, 10(1), 50-60. 
Elliott, S. ., Kratochwill, T. ., Cook, J. ., \& Travers, J. . (1996). Educational Psychology: Effective Teaching, Effective Learning (3rd ed.). Boston, MA: McGraw-Hill.

Ennis, R. . (1996). Critical Thinking. New Jersey: Prentice Hall, Inc.

Firdaus, Kailani, I., Bakar, M. N. ., \& Bakry. (2015). Developing Critical Thinking Skills of Students in Mathematics Learning. Journal of Education and Learning, 9(3), 226236.

Fisher, A. (2014). Berpikir Kritis. Jakarta: Erlangga.

Holme, T. A., Luxford, C. J., \& Brandriet, A. (2015). Defining Conceptual Understanding in General Chemistry. Journal of Chemical Education, 92, 1477-1483.

https://doi.org/10.1021/acs.jchemed. $5 \mathrm{~b} 00218$

Irawan, A. (2016). Peranan Kemampuan Numerik dan Verbal Dalam Berpikir Kritis Matematika pada Tingkat Sekolah Menengah Atas. AdMathEdu, 6(2), 121-130.

Irwandani, \& Rofiah, S. (2015). Pengaruh Model Pembelajaran Generatif Terhadap Pemahaman Konsep Fisika Pokok Bahasan Bunyi Peserta Didik MTS Al-Hikmah Bandar Lampung. Jurnal Ilmiah Pendidikan Fisika AlBiRuNi, 4(2), 165-177. https://doi.org/10.24042/jpifalbiruni. v4i2.90

James, A. ., \& Adewale, O. . (2012). The Relationship Between Senior Secondary Schools Students Achievement in Mathematical Problem-Solving and Intellectual Abilities Tests. European Scientific Journal, 8(15), 169-179.

Jumadi, Paidi, Atiarani, A., \& Siwi, R. . (2014). Pengembangan Perangkat Pembelajaran IPA Terpadu Model Susan Loucks-Horsley. European Scientific Journal, 44(1), 15 - 25.

Kola, A. J. (2017). Investigating the
Conceptual Understanding of Physics through an Interactive Lecture- Engagement. Cumhuriyet International Journal of Education, 6(1), 82-96.

Liliawati, W., Utama, J. ., \& Fauziah, H. (2016). Susan Loucks Horsley Learning Model in Light Pollution Theme. Journal of Physics. https://doi.org/10.1088/17426596/739/1/012141

Loucks-Horsley, S., Stiles, K. ., Mundry, S., Love, N., \& Hewson, P. . (2010). Designing Professional Development for Teacher of Science and Mathematics. California: Corwin.

Mabruroh, F., \& Suhandi, A. (2017). Construction of Critical Thinking Skills Test Instrument Related the Concept on Sound Wave. Journal of Physics.

https://doi.org/10.1088/17426596/812/1/012056

McCormack, A. . (1992). Science Curriculum Resource Handbook. New York: Kraus International Publications.

Muiz, A., Wilujeng, I., Jumadi, \& Senam. (2016). Implementasi Model Susan Loucks Horsley Terhadap Communication and Collaboration Peserta Didik SMP. UNNES Science Education Journal, 5(1), 1079-1084.

Nasrun. (2014). Contextual Learning Approach in Improving Critical Thinking Skill of Guidance and Counseling Students of The State University of Medan. International Journal of Science: Basic and Applied Research (IJSBAR), 18(1), 151-161.

Nurbaeti, Nuryanti, S., \& Puspitasari, I. . (2015). Hubungan Gaya Belajar dengan Keterampilan Berpikir Kritis dan Kemampuan Kognitif Siswa Pada Mata Pelajaran Kimia di Kelas X SMKN 1 Bungku Tengah. EJurnal Mitra Sains, 3(2), 24-33.

Nurhayati, A. ., Jumadi, Wilujeng, I., \& 
Senam. (2017). Developing a Science Learning Devices Based on Susan Loucks-Horsley Model to Improve Scientific Literacy and Communication and Collaboration Skills. International Journal of Sciences: Basic and Applied Research (IJSBAR), 36(4), 175-184.

Olatoye, R. ., \& Aderogba, A. . (2011). Performance of Senior Secondary School Science Students in Aptitude Test: The Role of Student Verbal and Numerical Abilities. Journal of Emerging Trends in Educational Research and Policy Studies (JETERAPS), 2(6), 431 - 435.

Purnamawati, D., Ertikanto, C., \& Suyatna, A. (2017). Keefektifan Lembar Kerja Siswa Berbasis Inkuiri untuk Menumbuhkan Keterampilan Berpikir Tingkat Tinggi. Jurnal Ilmiah Pendidikan Fisika Al-BiRuNi, 6(2), 209-219. https://doi.org/10.24042/Jipfalbiruni. V6i2.2070.

Raven, J. C., Court, J. H., \& Raven, J. (1977). Raven's Progressive Matrices and Vocabulary Scales. New York: Psychological Corporation.

Saleh, S. (2011). The Level of B.Sc.Ed Students' Conceptual Understanding of Newtonian Physics. International Journal of Academic Research in Business and Social Sciences, 1(3), 249-256.

Seifi, M., Haghverdi, M., \& Azizmohamadi, F. (2012). Recognition of Students Difficulties in Solving Mathematical Word Problems from the Viewpoint of Teachers. Journal of Basic and Applied Scientific Research, 2(3), $2923-2928$.

Vukovic, R. ., \& Lesaux, N. . (2013). The Relationship Between Linguistic Skills and Arithmetic Knowledge. Learning and Individual Differences, 23, 87-91.
Walgito, B. (2010). Pengantar Psikologi Umum. Yogyakarta: Andi Offset.

Widhiarso, W., \& Haryanto. (2015). Examining Method Effect of Synonym and Antonym Test in Verbal Abilities Measure. Europe's Journal of Psychology, 11(3), 419431.

Wulandari, A. Y. . (2017). Pembelajaran Menggunakan Pendekatan Konstruktivisme Berbantuan Media Animasi Komuter untuk Meningkatkan Keterampilan Berpikir Kritis mahasiswa. In Prosiding SNPS (Seminar Nasional Pendidikan Sains), Surakarta: FKIP UNS, 97-103.

Yazdi, M. (2017). Development and Validation of a Persian Verbal Analogies Test Using the Rasch Model. North American Journal of Psychology, 19(3), 561-572. 